\title{
Diagnosis of Equine Herpes Virus 4 Infection using Polymerase Chain Reaction
}

\author{
J. A. Vala ${ }^{1}$, M. D. Patel ${ }^{2 *}$, D. R. Patel ${ }^{3}$, U. V. Ramani ${ }^{4}$, \\ I. H. Kalyani ${ }^{3}$, P. H. Makwana ${ }^{3}$ and D. N. Desai ${ }^{3}$ \\ ${ }^{1}$ Veterinary Clinical Complex, ${ }^{3}$ Department of Veterinary Microbiology, ${ }^{4}$ Department of \\ Animal Biotechnology, College of Veterinary Science and Animal Husbandry, \\ NAU, Navsari, India \\ ${ }^{2}$ College of Agriculture, NAU, Waghai, India \\ *Corresponding author
}

\section{A B S T R A C T}

Keywords

EHV-4,

Diagnosis,

PCR

Article Info

Accepted:

10 October 2020

Available Online:

10 November 2020
EHV-4 is respiratory pathogen of domestic horses associated with outbreaks of respiratory disease. The present study was conducted to diagnose an EHV-4 infection among domestic horses using polymerase chain reaction. Total 12 nasal swabs were collected from horses showing symptoms of respiratory disease, unthrifyness and fever. DNA was extracted from all samples and it was subjected to polymerase chain reaction for identification of EHV-4 DNA in samples. Four samples found positive for having EHV-4 infection revealed single compact band of $189 \mathrm{bp}$. PCR has been proved as an effective, less time consuming and sensitive as well as specific diagnostic test for diagnosis of EHV-4 infection.

\section{Introduction}

The equine herpes viruses (EHV) are highly infective pathogens of all members of the Equidae family worldwide. Among all, EHV4 is mostly associated with the respiratory disease, generally termed as equine rhinopneumonitis. (Patel and Heldens, 2005). Both, EHV-1 and 4 are enzootic in Indian domestic horse populations and majority of horses show serological evidence of exposure to these viruses. The spread of virus among susceptible population occurs by means of direct contact, inhalation of aerosols, nasal secretion and ingestion of contaminated feed (Garre et al., 2009). Latency and reactivation are the key factors of epidemiology of EHV-1 and EHV-4 infections and are responsible for ubiquitous distribution of these viruses in equine population. EHV-4 infection is characterized by a short incubation time $(<1$ day) followed by transient elevation of body temperature $\left(38.9-41.0^{\circ} \mathrm{C}\right)$, in appetence, nasal discharge, pharyngitis, depression, enlarged submandibular lymph nodes, and occasional ocular discharge (Constable et al., 2017). Diagnosis of EHV-4 infection is mostly based on virus isolation (cell culture) 
and identification (polymerase chain reaction) as well as serological typing. Polymerase chain reaction has been widely proved to be quick, very sensitive and very reliable method for detection of EHV-1 and 4 infections, as both are often causing latent infections (Sarani et al., 2013). More recently, quantitative real-time PCR based assays have also been employed for a more sensitive detection and quantifying viral loads (Slater, 2014). The present study was carried out to diagnose EHV-4 infection by PCR at local regional laboratory.

\section{Materials and Methods}

The present study was conducted in south Gujarat, India. Individual cases were clinically investigated. The following parameters were included: fever (rectal temperature $>102.5^{\circ} \mathrm{F}$ ), unthriftyness and respiratory syndrome.

\section{Sampling and storage}

Total 12 horses with above symptoms were selected for sample collection. The nasal swabs were collected by inserting sterile collection swab inside nostril. The sterile collection swab was rubbed inside nostril as deep as possible and then put into appropriate sterile container. Each sample was labelled properly and immediately placed into cooler containing ice for transportation. The collected nasal swabs were stored at $-20^{\circ} \mathrm{C}$ untill further processing.

\section{Nucleic acid extraction and PCR amplification}

EHV-4 DNA was extracted from nasopharyngeal swabs using $\mathrm{VetPCR}^{\mathrm{TM}}$ EHV-4 (Bioingentech Ltd., Chile) detection kit according to manufacturer's instructions with final DNA elution volume of $50 \mu$ l. The DNA amplification was carried out in a final volume of $24.5 \mu \mathrm{l}$ PCR reaction mixture containing $2 \mu \mathrm{l}, 5.5 \mu \mathrm{l}$ of VetPCR ${ }^{\mathrm{TM}}$ EHV-4 premixture containing primers, dNTPs and DNA polymerase, $6 \mu$ l DNAse free water and $11 \mu \mathrm{l}$ of mineral oil to layer above it. The prepared reaction mixture was placed into thermal cycler and run as per following parameters.

The amplified PCR products were identified by using agarose gel electrophoresis.

\section{Results and Discussion}

Out of 12 horses enrolled in the study, 4 horses were PCR-positive for EHV-4 infection. It was found that protocol of initial denaturation (Stage-1) $94^{\circ} \mathrm{C} / 2$ minutes, 30 cycles of Stage- 2 denaturation $94^{\circ} \mathrm{C} / 30$ seconds, annealing $56^{\circ} \mathrm{C} / 30$ seconds, extension $72^{\circ} \mathrm{C} / 30$ seconds and final extension (Stage-3) $72^{\circ} \mathrm{C} / 5$ minutes yielded single compact band of 189 bp (Figure-1) for EHV-4.EHV-4 infection is endemic in horse population worldwide and can be isolated from both clinically normal and/or having upper respiratory tract infection with shedding of viruses in nasal discharge (Constable et al., 2017). Previously, the standard method for diagnosing the presence of viral pathogens mostly relies on culture and other techniques such as serum neutralization testing (SN), CSF analysis, ELISA which are time consuming and cumbersome but the sensitivity of PCR is much higher than these immunological methods. For diagnosis of EHV-4 infection, PCR has become the test of choice due to its high sensitivity and specificity. Nowadays, PCR has been routinely used as molecular diagnostic tool for equine herpes virus infections in various countries and many prevalence studies had been carried out using PCR as a single diagnostic tool (Ataseven et al., 2009; Mohamed et al., 2017; Negussie et al., 2017; Azab et al., 2019). 
Table.1 PCR cycling parameters

\begin{tabular}{|l|l|l|l|}
\hline PCR cycle & & Temperature & Time \\
\hline $\mathbf{1}$ cycle & Initial Denaturation & $94^{\circ} \mathrm{C}$ & 2 minutes \\
\hline $\mathbf{3 0}$ cycle & Denaturation & $94^{\circ} \mathrm{C}$ & $30 \mathrm{sec}$ \\
\cline { 2 - 4 } & Annealing & $52 / 53 / 54 / 55 / 56 / 57^{\circ} \mathrm{C}$ & $30 \mathrm{sec}$ \\
\cline { 2 - 4 } & Extension & $72^{\circ} \mathrm{C}$ & $30 \mathrm{sec}$ \\
\hline $\mathbf{1}$ cycle & Final extension & $72^{\circ} \mathrm{C}$ & 5 minutes \\
\hline
\end{tabular}

Fig.1 PCR detection of EHV-4 infection. L - DNA ladder (100 bp); Lane - 1 to 7 and 10 negative samples; Lane $-8,9,11,12$ positive samples (189 bp)

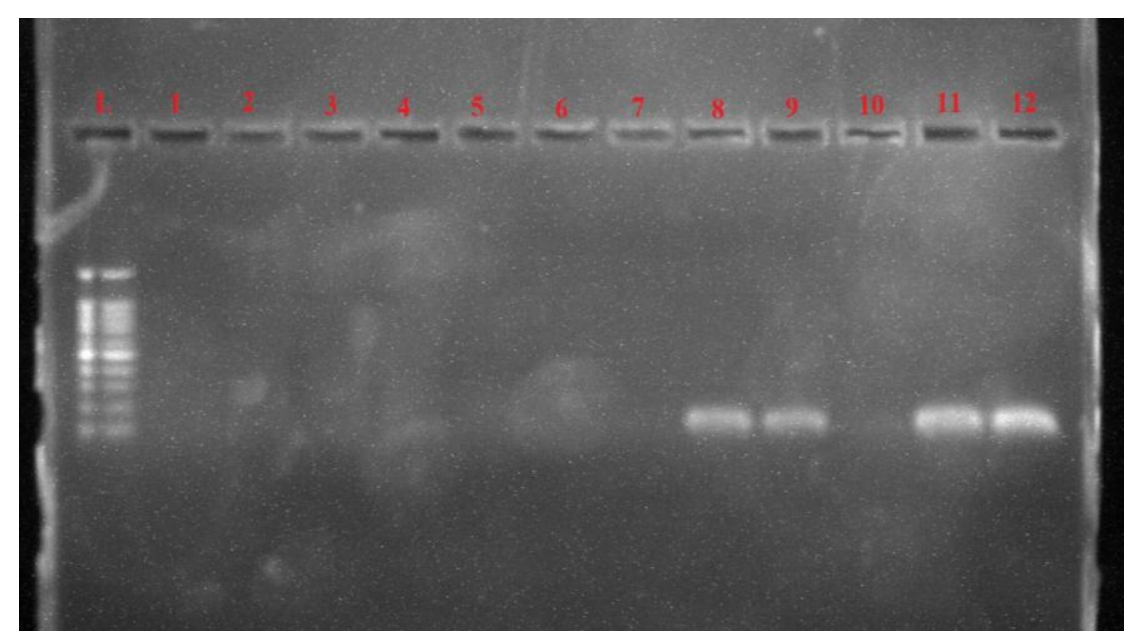

The present study was carried out in small scale only to standardize a PCR test for diagnosis of EHV-4 infection at local level. PCR has been proven as rapid and sensitive tool for diagnosis of EHV-4 infection. PCR can also act as a primary tool for investigation of molecular epidemiology as amplified viral genomes can further be sequenced. This allows further molecular characterization and inferences to be made regard to certain biological properties such as antigenicity and host range (Cathcart and Murcia, 2012). Development and wide level application of PCR diagnostic test in various part of India can throw a light on actual prevalence rate of EHV-4.

\section{Conflict of interest}

The authors have no conflict of interest.

\section{Acknowledgements}

We are thankful to Dean and Principal, College of Veterinary Science and Animal Husbandry, Navsari Agricultural University, Navsari, Gujarat, India and Navsari Agricultural University for allowance of this research work and provision of necessary funding.

\section{References}

Constable, P., Hinchcliff, K., Done, S. and Gruenberg, W. 2017.A textbook of diseases of cattle, horse, sheep, pigs and goat. $11^{\text {th }}$ Edition. Elsevier Health Sciences, London, United Kingdom. Pp1040-1042.

Slater, J. 2014. Equine herpes viruses, In: Equine Infectious Diseases (Eds.) D. 
Sellon and M. Long. Elsevier Health Sciences, London. United Kingdom. Pp. 151-168.

Patel, J. and Heldens, J. 2005. Equine herpes viruses 1 (EHV-1) and 4 (EHV-4) Epidemiology, disease and immunoprophylaxis: a brief review. The Veterinary Journal. 170:14-23.

Garre, B., Gryspeerdt, A., Croubels, S., De Backer, P. and Nauwynck, H. 2009. Evaluation of orally administered valacyclovir in experimentally EHV-1 infected ponies. Veterinary Microbiology. 135: 214-221.

Sarani, A., G. Mohammadi, Mayameei, A. and Akbari, M. 2013. Investigation of equine herpes virus-1 and 4 infections in equine population of Iran by realtime PCR.Human \& Veterinary Medicine. 5:29-33.

Ataseven, V., Dağalp, S., Güzel, M., Başaran, Z., Tan, M. and Geraghty, B. 2009. Prevalence of equine herpes virus-1 and equine herpes virus- 4 infections in equidae species in Turkey as determined by ELISA and multiplex nested PCR. Research in Veterinary
Science. 86:339-344.

Mohamed, S., Mohamed, A., El Deeb, A. and Salem, S. 2017. Prevalence of equine herpes viruses-1 and 4 in Arabian horses' population in Egypt. Journal of Virological sciences. 2:1-9.

Negussie, H., Gizaw, D., Tesfaw, L., Li, Y., Oguma, K., Sentsui, H., Tessema, T. and Nauwynk, H. 2017. Detection of equine herpesvirus (EHV) -1, 2, 4 and 5 in Ethiopian equids with and without respiratory problems and genetic characterization of EHV-2 and EHV-5 Strains. Transboundary and Emerging Diseases. 64:1970-1978.

Azab, W., Bedair, S., Abdelgawwad, A., Esche, K., Farag, G., Greenwood, A. and Osterrieder, N. (2019). Detection of equid herpes viruses among different Arabian horse populations in Egypt. Veterinary Medicine and Science. 5:361-371.

Cathcart, M. and Murcia, P. 2012. Hide and seek: diagnosing equine viral diseases using molecular biology techniques. Equine Veterinary Journal. 44:379-381.

\section{How to cite this article:}

Vala, J. A., M. D. Patel, D. R. Patel, U. V. Ramani, I. H. Kalyani, P. H. Makwana and Desai, D. N. 2020. Diagnosis of Equine Herpes Virus 4 Infection using Polymerase Chain Reaction. Int.J.Curr.Microbiol.App.Sci. 9(11): 887-890. doi: https://doi.org/10.20546/ijcmas.2020.911.106 